\title{
Pengetahuan dan Sikap Wanita Mengenai Kanker Serviks dan Pap Smear Di RSU. Hermana Lembean Bulan November- Desember Tahun 2013
}

\author{
Andrew Batas ${ }^{1}$, Mongan $S^{2}$, Maya Mewengkang ${ }^{2}$ \\ ${ }^{1}$ Mahasiswa Program Pendidikan S-1, Fakultas Kedokteran, Universitas Sam Ratulangi \\ ${ }^{2}$ Staf Pengajar, Pembimbing 1, Fakultas Kedokteran, Universitas Sam Ratulangi \\ ${ }^{3}$ Staf Pengajar, Pembimbing 2, Fakultas Kedokteran, Universitas Sam Ratulangi
}

\begin{abstract}
Cervical cancer is a very dangerous disease and is still a serious problem world-wide. It is estimated that there are approximately 500,000 new cases every year which mostly occur in developing countries. In recent years after the introduction of cervical cancer screening, the incidence of cervical cancer has decreased. This study aimed to describe the knowledge and attitude of women toward cervical cancer and Pap's smears. This study used a descriptive method. Samples were 50 women obtained by using a purposive sampling design. Data were collected by using questionnaires. The results showed that as many as 40 samples (80 \%) had good knowledge and 10 samples (20\%) had poor knowledge. Meanwhile, there were as many as 47 samples (94\%) showed agreement and 3 samples (6 \%) showed disagreement. Conclusion: Among most women in Hermana Lembean Hospital, education can affect their attitude toward cervical cancer.
\end{abstract}

Keywords: cervical cancer, Pap smear, attitude, knowledge

\section{ABSTRAK}

Kanker serviks merupakan suatu penyakit yang sangat berbahaya dan masih menjadi masalah yang serius di dunia. Selain itu, kanker serviks merupakan penyebab kematian terbanyak akibat penyakit kanker pada wanita. Diperkirakan setiap tahun ditemukan sekitar 500.000 kasus baru yang umumnya terjadi di negara berkembang. Dalam beberapa tahun terakhir insiden kanker serviks mengalami penurunan setelah skrining kanker serviks menjadi popular. Penelitian ini bertujuan untuk menggambarkan hubungan tingkat pengetahuan dan sikap wanita terhadap kanker serviks dan Pap's smear. Metode penelitian deskriptif dengan rancangan purposive sampling sebanyak 50 orang wanita. Pengumpulan data menggunakan kuesioner. Hasil penelitan memperlihatkan bahwa sebanyak 40 orang (80\%) sampel memiliki pengetahuan baik sedangkan 10 sampel (20\%) memiliki pengetahuan kurang baik. Untuk sikap, sebanyak 47 sampel (94\%) memiliki sikap setuju sedangkan 3 orang (6\%) memiliki sikap tidak setuju. Simpulan: Pada sebagian besar wanita-wanita di RSU Hermana Lembean, pengetahuan berpengaruh pada perilaku terhadap kanker serviks.

Kata kunci: kanker serviks, pap smear, sikap, pengetahuan

Kanker serviks merupakan suatu penyakit yang sangat berbahaya dan masih menjadi masalah yang serius di dunia. Di negara berkembang kanker serviks merupakan penyebab kematian terbanyak akibat penyakit kanker pada wanita. Diperkirakan setiap tahun dijumpai sekitar 500.000 penderita baru dan umumnya terjadi di negara berkembang. Sesungguhnya penyakit ini dapat dicegah bila program skrining sitologi dan pelayanan kesehatan diperbaiki. Namun, hingga saat ini program skrining belum lagi memasyarakat di negara berkembang, hingga mudah dimengerti mengapa insiden kanker serviks masih tetap tinggi. ${ }^{1}$ 
Di negara berkembang seperti Indonesia yang sebagian besar penduduknya adalah perempuan, kanker serviks merupakan salah satu penyakit yang sering ditemukan. Hal ini disebabkan karena masih kurangnya pengetahuan masyarakat terhadap penyakit ini. Juga, sebagian besar penderita penyakit ini adalah kaum perempuan ditingkat yang lemah ekonomi dan pendidikannya. ${ }^{2}$

Sebagian besar wanita pada usia produktif dapat terkena kanker serviks, tetapi sangat jarang ditemukan pada usia sebelum 20 tahun. Pertumbuhan kanker pada rentang usia 30-60 tahun relatif lebih cepat dan pada usia 40-60 tahun relatif tinggi. Dalam 10 tahun terakhir, insiden kanker serviks meningkat sebanyak 77\% pada usia 25- 34 tahun. $^{3}$

Kanker serviks hampir selalu terjadi pada wanita yang sedang atau pernah aktif secara seksual dan sebagian besar pasien kanker serviks uteri adalah wanita yang sudah menikah. ${ }^{4}$ Kehidupan seksual pertama yang terlalu dini serta mitra seksual yang terlalu banyak berkaitan erat dengan kanker serviks uteri. ${ }^{3}$ Terdapat bukti yang semakin jelas bahwa infeksi oleh strain human papilloma virus (HPV) tertentu merupakan satu faktor penyebab terjadinya kanker serviks. ${ }^{4}$

Dari data hasil survei rekam medik yang diambil dari RSU. Hermana Lembean terdapat 7 penderita pada tahun 2011 dan mengalami peningkatan menjadi 15 penderita pada tahuan 2013 dan sebagian besar adalah wanita dengan rentang usia 40-60 tahun.

Dalam beberapa tahun terakhir, di kabupaten minahasa utara sudah dilakukan berbagai upaya penyuluhan mengenai bahaya dari kanker serviks. Namun, sampai saat ini insiden kanker serviks masih meningkat di daerah tersebut. Melihat masalah yang terjadi, penulis tertarik untuk melakukan penelitian untuk menilai seberapa besar tingkat pengetahuan dan sikap wanita mengenai kanker serviks dan pemeriksaan pap smear di RSU. Hermana Lembean.

\section{Kanker Serviks}

Kanker leher rahim adalah tumor ganas yang mengenai lapisan permukaan (epitel) dari leher rahim atau mulut rahim, dimana sel-sel permukaan (epitel) tersebut mengalami penggandaan dan berubah sifat tidak seperti sel yang normal. Penggandaan sel yang tidak menuruti aturan yang normal itu dapat membentuk tumor atau dungkul kadang-kadang luka atau borok, yang memberi keluhan atau gejala keputihan yang berbau atau perdarahan. ${ }^{5}$

Tumor ganas pada serviks uteri ialah karsinoma. Sebagian besar berjenis epidermoid (91\%); adenokarsinoma hanya merupakan bagian kecil (9\%). Disamping itu, terdapat campuran antara epidermoid dan adenokarsinoma, dan jarang sekali ditemukan sarkoma. ${ }^{6}$

\section{Fakto Resiko}

\section{a. Hubungan Seksual}

Karsinoma serviks diperkirakan sebagai penyakit yang ditularkan secara seksual. Beberapa bukti menunjukkan adanya hubungan antara riwayat hubungan seksual dan risiko penyakit ini. Sesuai dengan etiologi infeksinya, wanita dengan partner seksual yang banyak dan wanita yang memulai hubungan seksual pada usia muda akan meningkatkan risiko terkena kanker serviks. ${ }^{7,8}$

\section{b. Karakteristik partner}

Studi kasus kontrol menunjukkan bahwa pasien dengan kanker serviks lebih sering menjalani seks aktif dengan partner yang melakukan seks berulang kali. Selain itu, partner dari pria dengan kanker penis atau partner dari pria yang istrinya meninggal terkena kanker serviks juga akan meningkatkan risiko kanker serviks. ${ }^{7}$ Cara mencegah timbulnya kanker serviks adalah dengan tidak berganti-ganti pasangan dan tidak berhubungan dengan pria yang suka berganti-ganti pasangan. ${ }^{8}$ 
c. Riwayat ginekologis

Walaupun usia menarche atau menopause tidak mempengaruhi risiko kanker serviks, hamil di usia muda dan jumlah kehamilan atau manajemen persalinan yang tidak tepat dapat pula meningkatkan risiko. ${ }^{7}$

d. Kontrasepsi

Kondom dan diafragma dapat memberikan perlindungan. Kontrasepsi oral yang dipakai dalam jangka panjang yaitu lebih dari 5 tahun dapat meningkatkan risiko relatif 1,53 kali. WHO melaporkan risiko relatif pada pemakaian kontrasepsi oral sebesar 1,19 kali dan meningkat sesuai dengan lamanya pemakaian. ${ }^{5,7}$

e. Virus herpes simpleks

Walaupun semua virus herpes simpleks tipe 2 (HPV-2) belum didemonstrasikan pada sel tumor, teknik hibridisasi insitu telah menunjukkan bahwa terdapat HPV RNA spesifik pada sampel jaringan wanita dengan displasia serviks. ${ }^{7}$

f. Merokok

Bahan karsinogenik spesifik dari tembakau dapat dijumpai dalam lendir dari mulut rahim pada wanita perokok. Bahan karsinogenik ini dapat merusak DNA sel epitel skuamosa dan bersama infeksi HPV dapat mencetuskan transformasi keganasan. Efek langsung bahan-bahan tersebut pada serviks adalah menurunkan status imun lokal sehingga dapat menjadi karsinogen infeksi virus. ${ }^{5,7}$

g. Lain-lain

Infeksi trikomonas, sifilis, dan gonokokus ditemukan berhubungan dengan kanker serviks. Namun, infeksi ini dipercaya muncul akibat hubungan seksual dengan multipel partner dan tidak dipertimbangkan sebagai faktor risiko kanker serviks secara langsung. ${ }^{7}$

\section{METODE PENELITIAN}

Penelitian ini menggunakan rancangan dan desain penelitan survey deskriptif dimana semua hasil olahan data akan di deskripsikan sesuai dengan jenis variabel penelian dalam bentuk tabel dan cara pengambilan sampel adalah menggunakan cara purposive sampling yaitu jumlah sampel seusai dengan keinginan peneliti yaitu sebesar 50 responden. Untuk instrumen penelitian yang digunakan adalah kuesioner dimana setiap sampel masing-masing akan dibagikan satu kuesioner.

Penelitian ini dilakukan selama 1 bulan yaitu dari bulan November sampai Desember dan untuk lokasi penelitian akan dilakukan di RSU. Hermana Lembean desa Lembean. Sampel yang akan diambil adalah semua wanita yang berkunjung di poliklinik RSU. Hermana Lembean yang disaring dengan kriteria inklusi yaitu wanita dengan usia diatas 18 tahun dan bersedia mengikuti penelitian.

Dalam penilaian tingkat pengethuan dan sikap akan menggunakan skala Guttman, diamana untuk setiap pertanyaan dengan jawaban 'ya' diberi nilai =1, sedangkan untuk jawaban 'tidak' diberi nilai=0. Untuk penilaian sikap, setiap pernyataan 'setuju' nilainya =1dan untuk pernyataan tidak setuju nilainya $=0$.

Untuk kategori pengetahuan 'baik' adalah responden dengan skoæ7 dari 10 pertanyaan dan untuk kategori ‘kurang baik’ adalah reponden dengan skor $\leq 6$ dari 10 pertanyaan. Untuk sikap, responden dengan sikap 'setuju' adalah dengan skoæ7 sedangkan untuk sikap 'tidak setuju' adalah responden dengan skor $\leq 6$. 


\section{HASIL DAN BAHASAN}

Tabel 1. Distribusi frekuensi berdasarkan kriteria dermografik

\begin{tabular}{ccc}
\hline Usia & $\mathbf{n}$ & $\mathbf{\%}$ \\
\hline$<30$ tahun & 20 & $40 \%$ \\
30-40 tahun & 13 & $26 \%$ \\
$>40$ tahun & 17 & $34 \%$ \\
Total & $\mathbf{5 0}$ & $\mathbf{1 0 0 \%}$ \\
\hline Pekerjaan & $\mathbf{n}$ & $\mathbf{\%}$ \\
\hline PNS & 1 & $2 \%$ \\
Wiraswasta & 7 & $14 \%$ \\
Ibu rumah & 39 & $78 \%$ \\
tangga & 3 & $6 \%$ \\
Lainnya & 3 & $\mathbf{1 0 0 \%}$ \\
Total & $\mathbf{5 0}$ & $\mathbf{\%}$ \\
\hline Pendidikan & $\mathbf{n}$ & $8 \%$ \\
\hline SD & 4 & $22 \%$ \\
SMP & 11 & $62 \%$ \\
SMA & 31 & $8 \%$ \\
Perguruan & 4 & $\mathbf{1 0 0 \%}$ \\
Tinggi & &
\end{tabular}

Berdasarkan tabel 1, dari hasil penelitian diperoleh bahwa responden terbanyak berada pada kelompok umur $<30$ tahun yaitu sebanyak 20 orang (40\%), diikuti oleh kelompok umur $>40$ tahun sebanyak 17 orang (34\%) dan umur 30-40 tahun sebanyak 13 orang (26\%).

untuk jumlah distribusi berdasarkan pekerjaan didapatkan bahwa jumlah terbanyak berada pada responden yang bekerja sebagai ibu rumah tangga sebanyak 39 orang (78\%), diikuti oleh wiraswasta 7 orang (14\%), kemudian diikuti oleh pekerjaan lainnya sebanyak 3 orang (6\%) dan PNS sebanyak 1 orang (2\%).

Sedangkan, untuk pendidikan responden terbanyak berada pada tingkat SMA sebanyak 31 orang (62\%), kemudian diikuti oleh tingkat SMP sebanyak 11 orang (22\%), dan diikuti oleh tingkat SD sebanyak 4 orang (8\%) dan perguruan tinggi sebanyak 4 orang (8\%).

Tabel 2. Distribusi frekuensi pengetahuan berdasarkan usia

Dari data hasil penelitian tingkat pengetahuan berdasarkan usia responden pada tabel 2, diperoleh data bahwa tingkat pengetahuan baik terbanyak berada pada kelompok usia $>40$ tahun, sedangkan untuk tingkat pengetahuan kurang baik terbanyak berada pada kelompok usia <30 tahun. Hal ini disebabkan karena adanya beberapa faktor yang mempengaruhi seperti pengalaman dan tingkat pengetahuan. Karena, wanita dengan usia yang lebih

\begin{tabular}{cccc}
\hline Usia & Baik & $\begin{array}{c}\text { Kurang } \\
\text { Baik }\end{array}$ & Total \\
\hline$<30$ thn & 12 & 8 & 20 \\
$\begin{array}{c}30-40 \\
\text { thn }\end{array}$ & 12 & 1 & 13 \\
$>40$ thn & 16 & 1 & 17 \\
\hline Total & $\mathbf{4 0}$ & $\mathbf{1 0}$ & $\mathbf{5 0}$ \\
\hline
\end{tabular}
tua cenderung lebih banyak menerima materi serta adanya proses pola pikir yang berbeda dengan usia muda sehingga menentukan besarnya nilai pengetahuan yang diperoleh.

Tabel 3. Distribusi frekuensi sikap berdasarkan usia

\begin{tabular}{cccc}
\hline Usia & Setuju & $\begin{array}{c}\text { Tidak } \\
\text { Setuju }\end{array}$ & Total \\
\hline$<30$ thn & 17 & 3 & 20 \\
$30-40$ thn & 13 & 0 & 13
\end{tabular}




$>40$ thn $\quad 17 \quad 0 \quad 17$

\begin{tabular}{llll}
\hline Total & 47 & 3 & 50 \\
\hline
\end{tabular}

Untuk hasil pengukuran sikap berdasarkan usia pada tabel 3, diperoleh bahwa responden yang memiliki sikap setuju terbanyak berada pada kelompok usia $>40$ tahun dan $<30$ tahun, sedangkan untuk sikap tidak setuju terbanyak berada pada kelompok usia $<30$ tahun. Hal ini disebabkan karena adanya perbedaan dalam berpikir dan cara pandang pada tiap kelompok usia berdasarkan pengalaman yang ada. Usia yang lebih tua biasanya lebih mau menerima sehingga dan merespon stimulus yang diberikan sehingga mampu bersikap positif.

Tabel 4. Distribusi frekuensi pengetahuan berdasarkan pekerjaan

\begin{tabular}{cccc}
\hline Pekerjaan & Baik & $\begin{array}{c}\text { Kurang } \\
\text { baik }\end{array}$ & Total \\
\hline PNS & 1 & 0 & 1 \\
Wiraswasta & 6 & 1 & 7 \\
$\begin{array}{c}\text { Ibu rumah } \\
\text { tangga } \\
\text { Lainnya }\end{array}$ & 32 & 7 & 39 \\
\hline Total & 1 & 2 & 3 \\
\hline
\end{tabular}

Dari hasil penelitian pada tabel 4 diperoleh data bahwa responden dengan pekerjaan ibu rumah tangga memiliki tingkat pengetahuan baik terbanyak yaitu sebanyak 32 orang, sedangkan untuk tingkat pengetahuan buruk terbanyak juga dimiliki oleh ibu rumah tangga.

Tabel 5. Distribusi frekuensi pengetahuan berdasarkan sikap

\begin{tabular}{cccc}
\hline Pekerjaan & Setuju & $\begin{array}{c}\text { Tidak } \\
\text { Setuju }\end{array}$ & Total \\
\hline PNS & 1 & 0 & 1 \\
Wiraswasta & 7 & 0 & 7 \\
$\begin{array}{c}\text { Ibu rumah } \\
\text { tangga } \\
\text { Lainnya }\end{array}$ & 37 & 2 & 39 \\
\hline Total & 2 & 1 & 3 \\
\hline
\end{tabular}

Hal serupa juga terlihat pada tabel 5 untuk sikap setuju terbanyak berada pada responden dengan pekerjaan ibu rumah tangga yaitu sebanyak 37 orang dan untuk sikap tidak setuju terbanyak juga berada pada kelompok pekerjaan ibu rumah tangga.

Hal ini disebabkan karena adanya beberapa faktor seperti lingkungan, sosial budaya, intelegensi dan media massa yang mempengaruhi pengetahuan dan sikap. Dimana, sebagian besar wanita di daerah 
tempat penelitian memiliki pekerjaan sebagai ibu rumah tangga. Selain itu, ibu rumah tangga juga dapat lebih menjangkau sumber - sumber informasi seperti melalui media massa dan berbagai kegiatan penyuluhan yang dilaksanakan.

Tabel 6. Distribusi frekuensi pengetahuan berdasarkan pendidikan terakhir

\begin{tabular}{cccc}
\hline Pendidikan & Baik & $\begin{array}{c}\text { Kurang } \\
\text { Baik }\end{array}$ & Total \\
\hline SD & 2 & 2 & 4 \\
SMP & 11 & 0 & 11 \\
SMA & 24 & 7 & 31 \\
Perguruan & 3 & 1 & 4 \\
Tinggi & & & \\
\hline Total & $\mathbf{4 0}$ & $\mathbf{1 0}$ & $\mathbf{5 0}$ \\
\hline
\end{tabular}

Pada tabel 6, merupakan gambaran distribusi tingkat pengetahuan berdasarkan pendidikan terakhir. Hasil penelitian diperoleh data bahwa responden dengan tingkat pendidikan terakhir SMA memiliki tingkat pengetahuan baik terbanyak yaitu 24 orang, sedangkan untuk tingkat pengetahuan kurang baik terbanyak juga dimiliki oleh tingkat SMA yaitu 7 orang.

Tabel 7. Distribusi frekuensi pengetahuan berdasarkan pendidikan terakhir

\begin{tabular}{cccc}
\hline Pendidikan & Setuju & $\begin{array}{c}\text { Tidak } \\
\text { Setuju }\end{array}$ & Total \\
\hline SD & 3 & 1 & 4 \\
SMP & 11 & 0 & 11 \\
SMA & 29 & 2 & 31 \\
Perguruan & 4 & 0 & 4 \\
Tinggi & & & \\
\hline Total & $\mathbf{4 7}$ & $\mathbf{3}$ & $\mathbf{5 0}$ \\
\hline
\end{tabular}

Hal ini juga dapat ditemukan pada tabel 7, dimana responden dengan tingkat pendidikan terakhir SMA memiliki sikap setuju terbanyak yaitu sebanyak 29 orang dan untuk sikap tidak setuju terbanyak juga pada tingkat SMA yaitu sebanyak 2 orang.

Beberapa faktor seperti lingkungan, pendidikan dan intelegensi dapat mempengaruhi tingkat pengetahuan dan sikap wanita. Hal ini dapat dilihat dari segi lingkungan yang merupakan lingkungan pedesaan, dimana sebagian besar masyarakat hanya mencapai tingkat pendidikan SMA sehingga wanita dengan latar belakang pendidikan SMA cenderung memiliki pengetahuan lebih karena adanya informasi yang dapat dijangkau ditambah juga dengan adanya sosialisasi dan penyuluhan yang dilaksanakan.

\section{SIMPULAN}

Berdasarkan hasil penelitian dapat disimpulkan bahwa pada sebagian besar wanita-wanita di RSU Hermana Lembean tingkat pengetahuan sangat penting dalam membentuk sikap dan perilaku. Tingkat pengetahuan yang lebih tinggi dapat mempermudah seseorang dalam menerima dan menentukan respon terhadap stimulus yang diberikan. Sebagian wanita mampu bersikap positif walaupun memiliki pengetahuan dibawah rata-rata, sebaliknya sebagian wanita dengan pengetahuan baik kurang mampu menentukan sikap oleh karena berbagai alasan seperti malu, takut dan biaya pemeriksaan terasa mahal. 


\section{DAFTAR PUSTAKA}

1. Prawirohardjo S.Buku Acuan Nasional Onkologi Ginekologi. Edisi pertama.Jakarta: Yayasan Bina Pustaka Sarwono Prawirohardjo; 2006.

2. Hasan N. Bahaya kanker serviks. 2012 (diakses 10 Sept 2013). Diambil dari : http://www.jurnalperempuan.org/bahaya-kanker-serviks.html

3. Desen W.Buku Ajar Onkologi Klinis. Edisi ke-2. diterjemahkan oleh: Japaries, W.Jakarta: Balai Penerbit FKUI; 2011.

4. Llewellyn D.Dasar-dasar Obstetri \& Ginekologi. Edisi ke-6. diterjemahkan oleh: dr. Hadyanto.Jakarta: Hipokrates; 2002.

5. Wulandari AS. Pengertian dan pemahaman resiko ca cerviks pada wanita usia subur di Indonesia.2010 (diakses 10 Sept 2013). Diambil dari:

http://elib.fk.uwks.ac.id/asset/archieve/jurnal/Vol2.no1.Januari2010/PENGERTIAN\%20DAN\%20PEMA HAMAN\%20RESIKO\%20CA\%20CERVIX\%20PADA.pdf

6. Djamaloedin, Albar E, Winkjosatro H, Hutabarat H, Husodo L, Joedosepoerto, et al. Ilmu kandungan. Editor: Anwar M, Baziaf A, Prabowo P.Edisi ke-3. Jakarta: Yayasan bina pustaka; 2011.

7. Rasjidi I. Epidemiologi kanker serviks. Indonesian Jurnal of Cancer. 2009;3:103-8.

8. Mandal A. Pencegahan kanker serviks. 2013 (diakses 21 Spet 2013). Diambil dari: http://www.newsmedical.net/health/Cervical-Cancer-Prevention.aspx 